\title{
PERBANDINGAN PENGUJIAN KONSOLIDASI MENGGUNAKAN ALAT ROWE CELL DAN OEDOMETER PADA TANAH LANAU LUNAK
}

\author{
Iskandar ${ }^{1}$, Rabiya $^{2}$ \\ ${ }^{1}$ Jurusan Teknik Sipil,Politeknik Negeri Bandung,Bandung 40012 \\ E-mail : iskandarpalembang1963@gmail.com \\ ${ }^{2} J u r u s a n$ Teknik Sipil,Politeknik Negeri Bandung,Bandung 40012 \\ E-mail :Rabiya86@yahoo.co.id
}

\begin{abstract}
ABSTRAK
Pengujian konsolidasi tanah menggunakan alat oedometer dan rowe cell. Oedometer sering kali digunakan pada tanah lempung maupun tanah lunak. Tetapi, dalam pengembangannya alat rowe cell dapat mendapatkan hasil penurunan tanah lunak yang lebih baik dari oedometer. Dari rowe cell ini keunggulannya adalah dapat mengetahui nilai kejenuhan dari contoh tanah yang diuji. Penggunaan alat uji rowe cell dapat mengukur tekanan air pori pada awal dan akhir setiap tahap konsolidasi. Rowe cell ini dapat memberikan hasil penurunan yang cocok untuk tanah lunak. Uji konsolidasi ini untuk mendapatkan parameter dari penurunan tanah.
\end{abstract}

Kata Kunci: Konsolidasi Tanah, Rowe Cell, Oedometer

\section{ABSTRACT}

Soil consolidation testing using an oedometer and Rowe cell. Oedometers are often used on clay and soft soils. However, in the development of the Rowe cell device, the results of settlement value were using Rowe cell. The advantage of cell Rowe device is able to determine pore water pressure, soil saturation, and back pressure of soil samples during consolidation process as a simulation of field condition. The consolidation test can be determined settlement of soil.

Keywords: Soil Consolidation, Rowe Cell, Oedometer

\section{PENDAHULUAN}

Banyak sekali dijumpai permasalahan penurunan pada tanah lunak. Permasalahan tersebut dikarenakan tanah memiliki sifat kembang susut besar, kadar air yang tinggi dan daya dukung rendah. Untuk mengetahui hal tersebut dilakukan pengujian penurunan dengan cara konsolidasi. Konsolidasi bisa dilakukan menggunakan alat rowe cell dan oedometer. Masing-masing dari alat memiliki keunggulan dan kelemahan yang berbeda. Rowe cell bisa mengetahui nilai konsolidasi pada tanah dengan beban tekanan air dan angin. Sedangkan oedometer menggunakan beban keping baja. Secara detail dari hasil penurunan yang lebih akurat, dapat dipakai dengan alat rowe cell. Alasannya disebabkan rowe dapat mengontrol penjenuhan tanah sebelum terjadinya konsolidasi.

\section{STUDI LITERATUR}

(A Zhafirah A K Somantri and S Permana ; 2019), menganalisis oedometer dan rowe cell pada tanah lempung lunak dibandingkan untuk pengujian eksperimental. Dari hasil pengujian dapat disimpulkan bahwa analisis parameter konsolidasi tanah menggunakan rowe cell dapat memprediksi penurunan konsolidasi di lapangan dengan lebih akurat dibandingkan oedometer. (Olek B S and Pilecka E ; 2019), pengukuran simulasi penurunan menggunakan rowe cell. Dari hasil pengujian dapat disimpulkan bahwa metode garis dalam rowe cell dapat diaplikasikan untuk di lapangan, yaitu kurva konsolidasi dari pengujian dapat menentukan konsolidasi tahap kedua. (Salleh M A et al ; 2020), melakukan penelitian material Palm Kernel Oil-Based Polyurethane Foam menggunakan rowe cell untuk perbaikan tanah. Dari hasil penelitian menunjukkan bahwa material tersebut yang dicampurkan dengan isocyanate and polyol liquid dapat meningkatkan kompresibilitas. 
(M Yuswandono A Suyono and R Rabiya ; 2020), melakukan penentuan konsolidasi tanah gambut menggunakan rowe cell. Dari hasil pengujian Cc yang didapat sebesar 0.50 dan nilai $\mathrm{Cv}$ sebesar $167.99 \mathrm{~cm}^{2}$. Dari hasil koefisien konsolidasi tersebut menunjukkan bahwa tanah gambut mengalami penurunan yang sangat cepat. (M Yuswandono A Suyono and R Rabiya ; 2020), membandingkan rowe cell dan oedometer untuk konsolidasi parameter tanah gambut. Dari hasil pengujian dapat disimpulkan bahwa kedua alat tersebut memiliki nilai koefisien konsolidasi yang sangat berbeda.Hasil konsolidasi oedometer detail lebih rendah nilai $\mathrm{Cv}$ dari pada menggunakan rowe cell. Hal tersebut dikarenakan oedometer tidak memiliki tingkat akurasi kejenuhan yang sempurna.

Dari literatur yang sudah dilakukan, perbedaan dari penelitian ini adalah penggunaan konsolidasi alat rowe cell dibandingkan dengan oedometer pada tanah lanau lunak. Biasanya yang ditemui pada dua alat pengujian ini adalah parameter tanahnya yang berbeda. (Thi N N et al ; 2020), melakukan penelitian untuk koefisien konsolidasi horizontal pada tanah lunak Vietnam. Dari hasil yang dilakukan mengindikasi bahwa nilai Ch selalu lebih besar daripada koefisien konsolidasi secara vertikal (Cv). Rasio $\mathrm{Ch} / \mathrm{Cv}$ tergantung pada tekanan konsolidasi, jenis tanah, dan tanah anisotropis. Itu adalah keperluan untuk memilih nilai $\mathrm{Ch}$ pada level tegangan konsolidasi untuk menghitung jarak PVD. (K B Mathews et al ; 2020), melakukan penelitian karbon dari pohon terhadap mitigasi pengubahan bencana. Dari hasil tersebut, tanah organik dapat memicu adanya pergerakan karbon. (B S Olek ; 2020), melakukan penelitian tentang konsolidasi tekanan 1 dimensi dengan tekanan air pori. Berdasarkan karakteristiknya, hubungan antara koefisien konsolidasi dan derajat dissipasi, range konsolidasi dapat dilengkapi dengan asumsi teori yang sudah ada. Konsolidasi rowe cell dengan mengukur tekanan air pori dapat mengetahui tentang faktor-faktor dari proses konsolidasi. (Kolay P K, Sii H Y and Taib S N L ; 2012), melakukan penelitian tentang karakteristik kompresibilitas gambut menggunakan rowe cell. Dari hasil penelitian menunjukkan bahwa rowe cell dapat digunakan untuk menyimulasikan ke dalam penerapan di lapangan. Sehingga didapat karakteristik geoteknik gambut dari desain atau modeling numerik dimana kecocokan data sangat penting.(R K Rowe and M A Dist ; 2020), melakukan penelitian design dan konstruksi berhubungan dengan faktor geomembrane. Proyek tersebut untuk mengetahui adanya geomembrane pada tanah lempung.

\subsection{Standar Pengujian}

Standar pengujian konsolidasi berdasarkan pada ASTM D2435-89. Konsolidasi rowe cell menggambarkan suatu tekanan total yang diaplikasikan dengan tekanan hidrolik. Pengaturan kontrol tekanan melalui kondisi yang dialirkan, mendapat hasil penjenuhan secara singkat dan cepat pada saat terjadi pembebanan untuk mengukur tekanan pori. Sedangkan konsolidasi oedometer menggunakan beban tekan keping baja. Untuk penjenuhan tidak bisa terlihat nilainya. Hanya bisa melihat penurunan tanah saja. Berikut adalah gambar rowe cell dan oedometer terlihat pada Gambar 1.
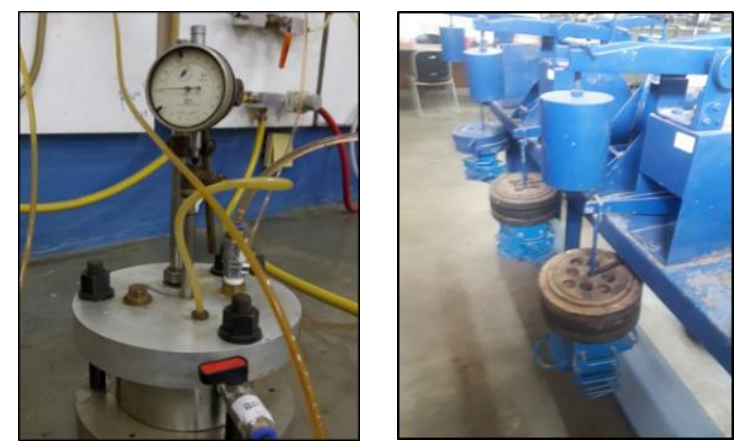

Gambar 1. Rowe Cell dan Oedometer

\section{METODE PENELITIAN}

Adapun tahap-tahap yang dilakukan saat penelitian berlangsung, yaitu dimulai dari pengambilan sampel, selanjutnya sampel tanah diuji konsolidasi menggunakan alat rowe cell dan oedometer. Rowe cell dilakukan 4 tahap pengujian terdiri dari tahap persiapan, tahap penjenuhan, tahap konsolidasi dan tahap setelah konsolidasi. Sedangkan alat oedometer dilakukan dengan 3 tahap, yaitu tahap persiapan, tahap penjenuhan dan tahap konsolidasi. Metode penelitian dapat terlihat pada Gambar 2. 
Vol. 22, No. 2, Oktober 2020

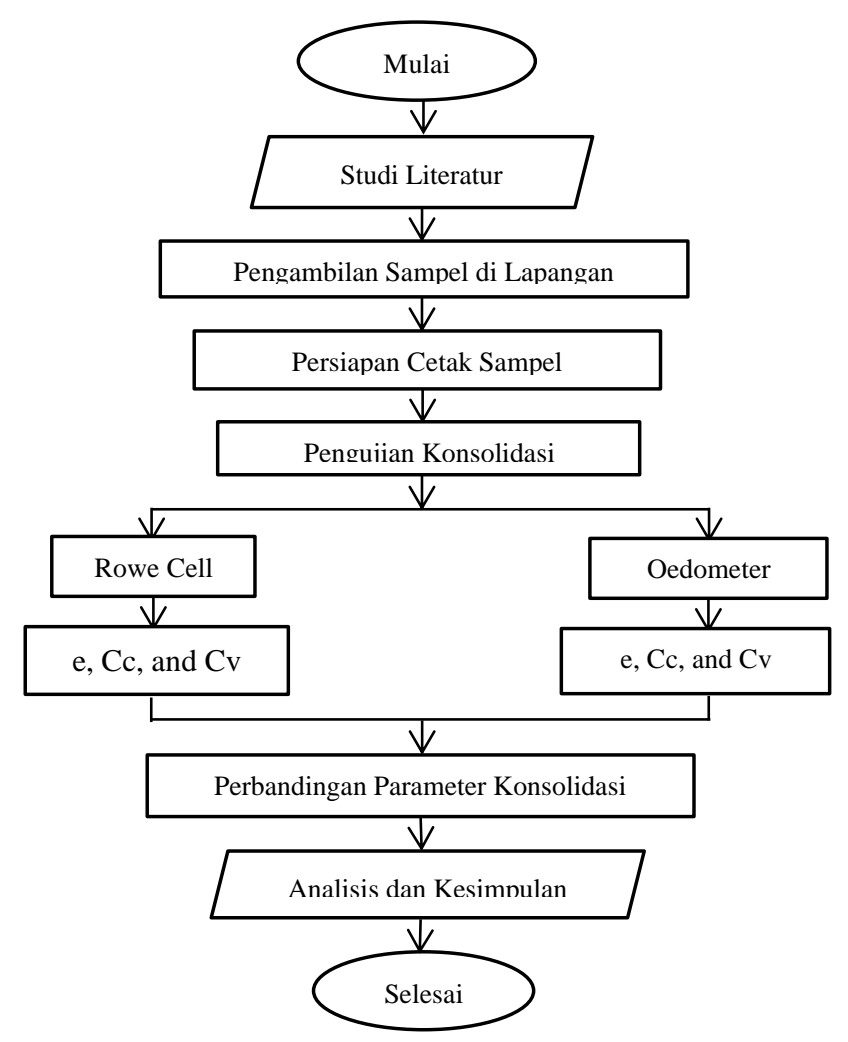

\section{HASIL PENGUJIAN}

Gambar 2. Diagram alir Umum Penelitian

Ada dua pengujian konsolidasi pada tanah lanau lunak. Dari hasil pengujian tersebut terdapat nilai e, $\mathrm{Cc}$ dan $\mathrm{Cv}$.

\subsection{Rowe Cell}

Pengujian konsolidasi Rowe Cell dilakukan sebanyak satu sampel, hasil pengujian dapat dilihat pada Gambar 3, Gambar 4 dan Gambar 5.

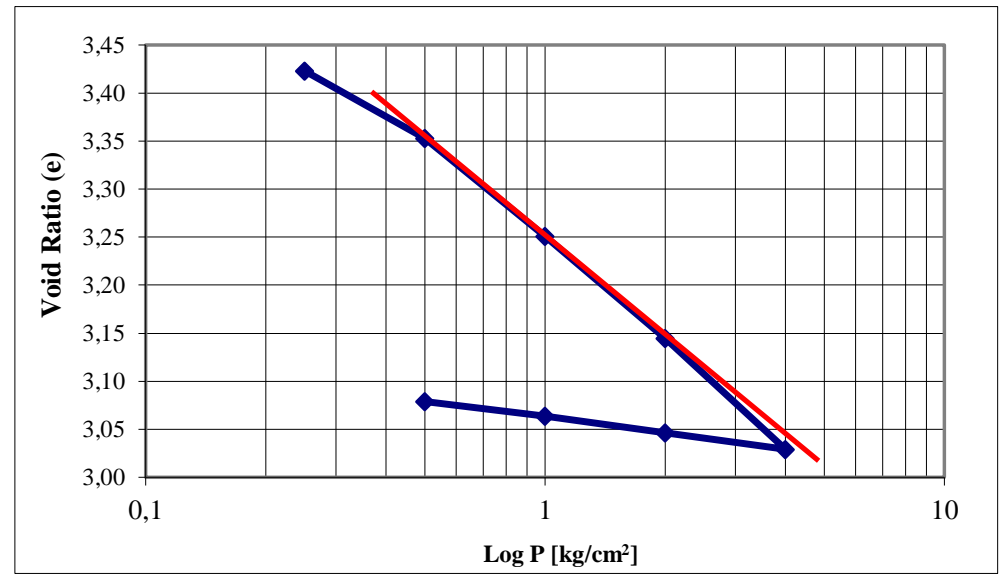

Gambar 3. Grafik Penurunan akar waktu

Dari hasil grafik pada Gambar 3 menunjukkan bahwa nilai e yang terdapat pada pengujian Rowe Cell adalah 3.2028 dan nilai Cc sebesar 0.368 


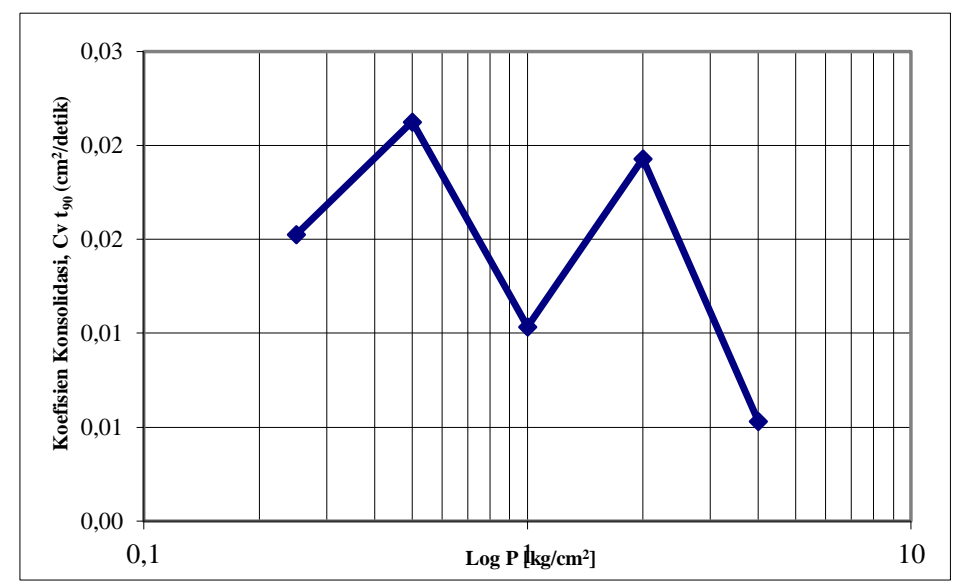

Gambar 4. Grafik konsolidasi Cv t90

Untuk menentukan koefisien konsolidasi yaitu dilakukan parameter yang didukung oleh Cv t90 dari Rowe Cell dan beban. Nilai Cv t90 yang didapat sebesar $1.19 \times 10^{-2} \mathrm{~cm}^{2} /$ detik.

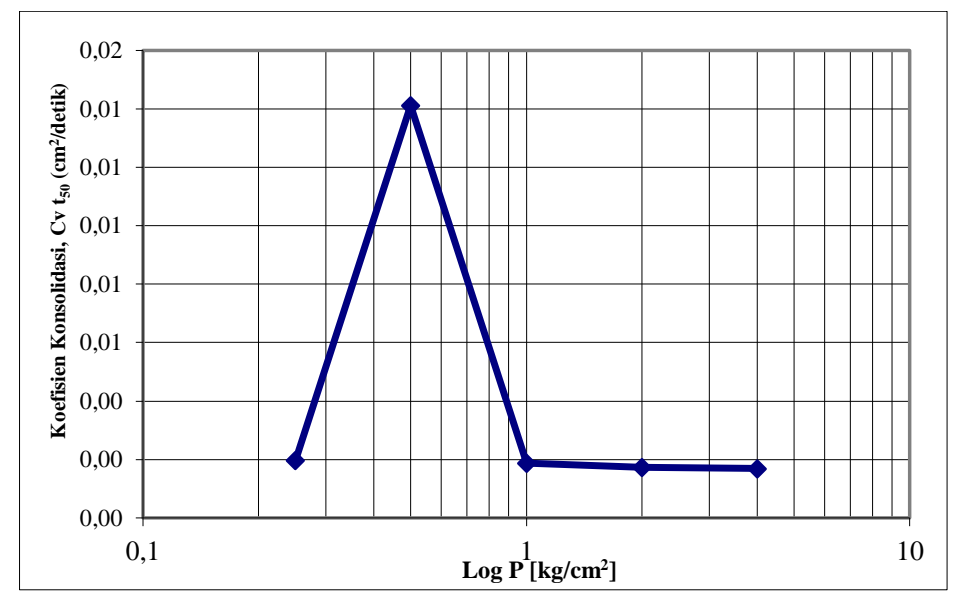

Gambar 5. Grafik konsolidasi Cv $\mathrm{t}_{50}$

Selain mendapatkan nilai $\mathrm{Cv} \mathrm{t}_{90}$ dari Gambar 4 dapat juga diketahui nilai $\mathrm{Cv} \mathrm{t}_{50}$ dari hasil data pengujian konsolidasi Rowe Cell (terlihat pada Gambar 5). Nilai Cv t50 yaitu sebesar $3.57 \times 10^{-3} \mathrm{~cm}^{2} /$ detik.

\subsection{Oedometer}

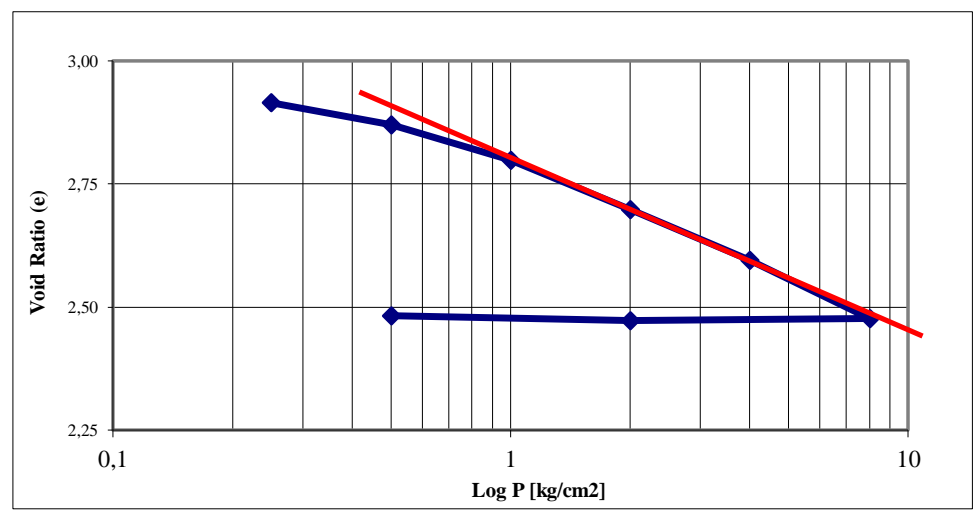

Gambar 6. Grafik Penurunan akar waktu

Hasil perbandingan dari Rowe Cell dapat dibandingkan dengan Oedometer. Nilai angka pori (e) yang didapat adalah 2.693 terlihat pada Gambar 6. Sedangkan nilai Cc yang didapat adalah 0.367. 


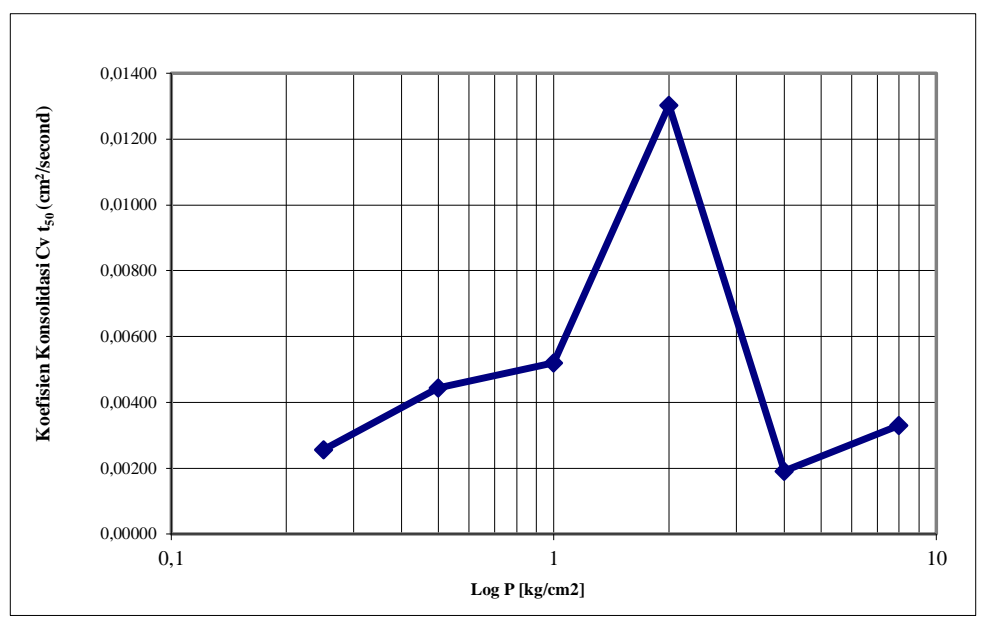

Gambar 7. Grafik konsolidasi Cv $t_{50}$

Pada Gambar 7 menunjukkan hasil nilai koefisien konsolidasi tanah. Koefisien konsolidasi tanah dengan waktu $50 \%$ terkonsolidasi sebesar $5.07 \times 10^{-3} \mathrm{~cm}^{2} /$ detik.

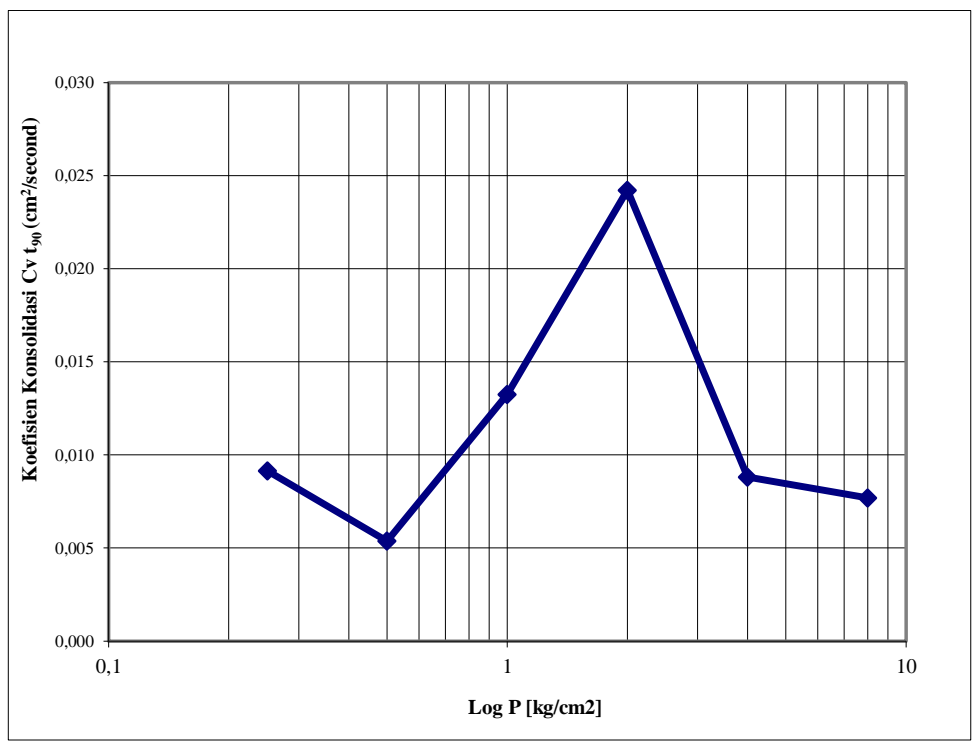

Gambar 8. Grafik konsolidasi Cv t90

Terlihat pada Gambar 8 menunjukkan grafik koefisien konsolidasi. Untuk tanah yang terkonsolidasi dengan waktu sebesar $90 \%$ sebesar $1.14 \times 10^{-2} \mathrm{~cm}^{2} /$ detik.

\section{ANALISIS HASIL PENGUJIAN}

Pengujian konsolidasi pada tahap mencapai tekanan air pori (pore water pressure), tanah dapat terkontrol terhadap beban yang digunakan. Tanah tersebut ditekan dan menghasilkan nilai dari tekanan balik (back pressure). Untuk mengetahui tanah tersebut jenuh atau tidak, hasil tanah tersebut mencapai derajat kejenuhan (Sr) sebesar 90\%. Penggunaan ketiga parameter yaitu tekanan air pori (pore water pressure), tekanan balik (back pressure), dan derajat kejenuhan (Sr) perlu digunakan saat menggunakan alat tersebut. Hasil yang dikeluarkan tergantung dari tanah yang diuji.

Dari hasil perbandingan konsolidasi dari dua alat (Rowe Cell dan Oedometer) menunjukkan nilai yang tidak terlalu signifikan bedanya. Dikarenakan sampel yang digunakan adalah tanah lanau lunak dan memiliki parameter yang sama. Tetapi jika dilihat dari nilai angka pori sedikit berbeda. Alasan tersebut ditimbulkan karena Rowe Cell dapat mengontrol nilai penjenuhan menjadi 90\% sampai 99\% sedangkan Oedometer tidak dapat menunjukkan hasil nilai penjenuhan. Untuk dapat lebih jelasnya nilai konsolidasi dari dua alat tersebut dapat dilihat pada Gambar 9, Gambar 10 dan Gambar 11. 


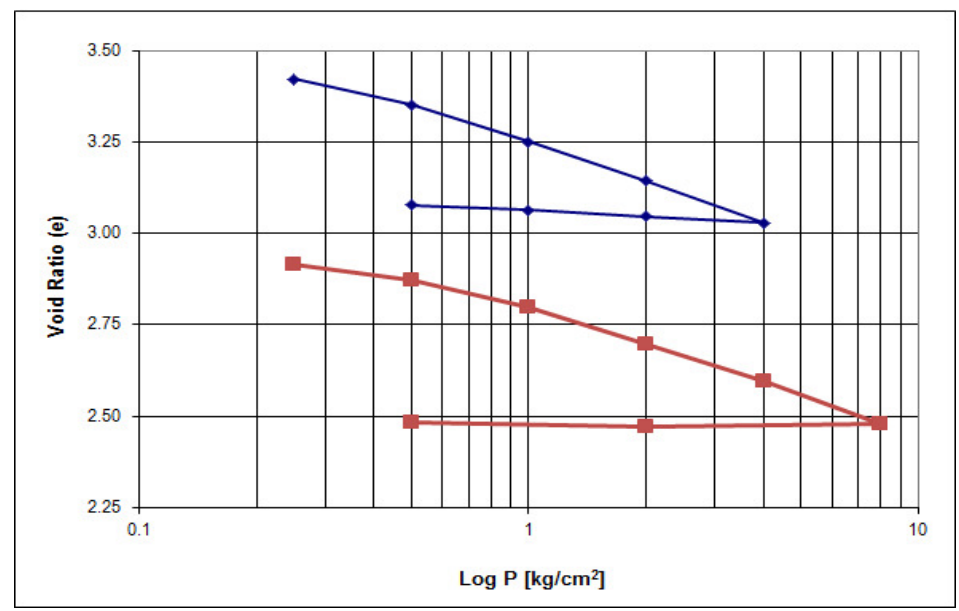

Gambar 9. Grafik Perbandingan Nilai Angka Pori pada Kedua Alat

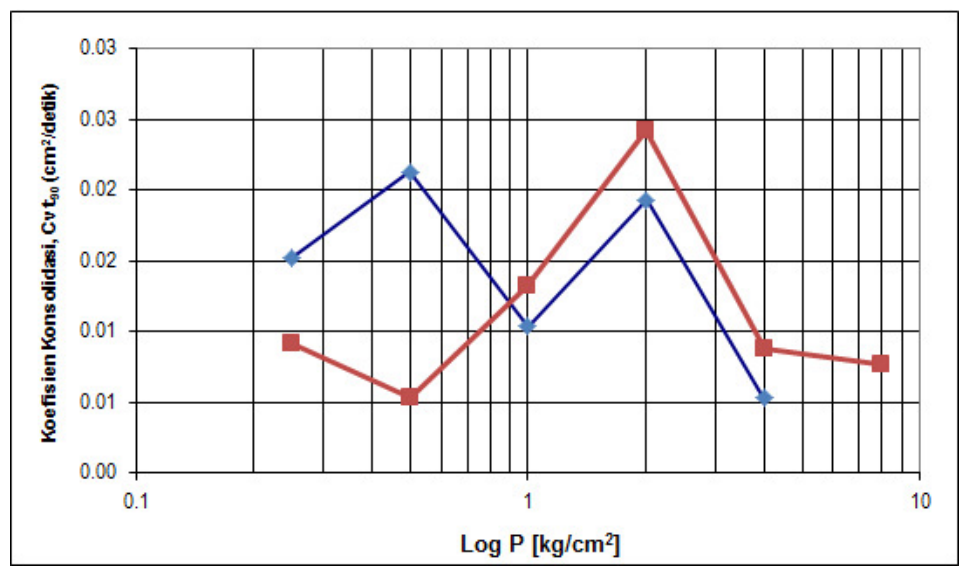

Gambar 10. Grafik Perbandingan Konsolidasi Cv t9o pada Kedua Alat

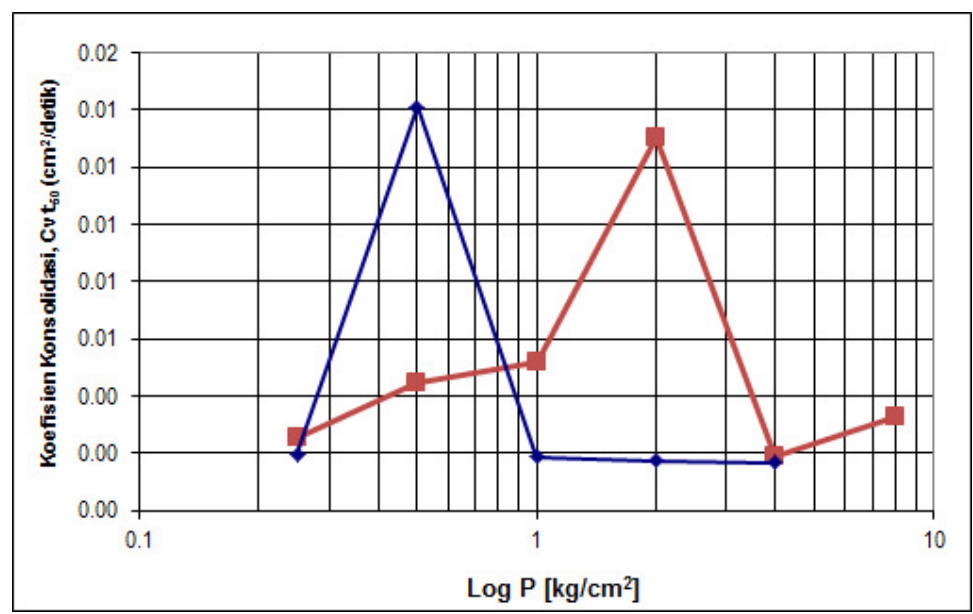

Gambar 11. Grafik Perbandingan konsolidasi Cv t9o pada Kedua Alat

\section{KESIMPULAN}

Kesimpulan yang dapat diambil dari penelitian ini adalah terdapat parameter-parameter konsolidasi yaitu angka pori (e), Cc dan Cv. Untuk nilai Cc dan Cv pada Rowe Cell adalah 0.4 dan 1.2 x 10-2 $\mathrm{cm}^{2} /$ detik. Nilai angka pori (e) adalah 3.2. Sedangkan untuk nilai $\mathrm{Cc}$ dan $\mathrm{Cv}$ pada Oedometer sebesar 0.4 dan $1.1 \times 10^{-2} \mathrm{~cm}^{2} /$ detik. Nilai angka pori (e) adalah 2.7 . Jadi, hasil membuktikan bahwa indeks konsolidasi Oedometer dan Rowe Cell tidak terlalu signifikan berbeda yang terdapat pada jenis tanah lanau lunak. Hasil pengujian ini dapat diterapkan untuk perencanaan geoteknik struktur bangunan. Sehingga, bisa dikaitkan dengan pemakaian jenis tanah yang digunakan. 


\section{UCAPAN TERIMA KASIH}

Ucapan terima kasih kepada Jurusan Teknik Sipil Politeknik Negeri Bandung, Teknisi Laboratorium Mekanika tanah Teknik Sipil Politeknik Negeri Bandung dan rekan-rekan yang terkait yang telah membantu proses kelancaran penelitian.

\section{DAFTAR PUSTAKA}

[1] A Zhafirah, A K Somantri, and S Permana," Analysis of Oedometer and Rowe Cell Consolidation Compared to Experimental Testing”, Department of Civil Engineering, Sekolah Tinggi Teknologi Garut, 2019, Journal of Physics: Conference Series 1402 (2019) 022006 doi: 10.1088/1742-6596/1402/2/022006, pp. 1-6.

[2] Olek B S and Pilecka E, "Large-Scale Rowe Cell Experimental Study on Coefficient of Consolidation of Coal Mine Tailings", Cracow University of Technology, 2019, International Scientific Conference on Civil EngineeringInfrastructure-Mining, 106,01004 doi.org/10.1051/e3sconf/201910601004, pp. 1-8.

[3] Salleh M A et al, "Compressibility of Palm Kernel Oil-Based Polyurethane Foam Using Rowe Cell Apparatus for Ground Improvement" , Faculty of Civil Engineering University Teknologi MARA, 2020, ISSN: 1662-9795, Vol. 844, doi:10.4028/www.scientific.net/KEM.844.24, pp. 24-31.

[4] M Yuswandono, A Suyono and R Rabiya, "Rowe Cell Testing to Determined Peat Soil Consolidation Parameter", Department of Civil Engineering Bandung State Polytechnic, 2020, IOP Conference Series: Materials Science and Engineering 732 (2020) 012025 doi: 10.1088/1757-899X/732/1/01/2025, pp. 1-6.

[5] M Yuswandono, A Suyono and R Rabiya, "Comparison of Rowe Cell and Oedometer Test to Determine Peat Soil Consolidation Parameters", Department of Civil Engineering Bandung State Polytechnic, 2020, IOP Conference Series: Materials Science and Engineering 830 (2020) 022053 doi: 10.1088/1757-899X/830/2/022053, pp. 1-6

[6] Thi N N, Son B T and Ngoc D M, "Research on Horizontal Coefficient of Consolidation of Vietnam's Soft Soil", Hanoi University of Mining and Geology, 2020, Journal of Engineering, Volume 2020, Article ID 3697689, http://doi.org/10.1155/2020/3697689, pp. 1-13.

[7] K B Matthews, D W Johnson, D Miller et al, "Not seeing the carbon for the trees?Why are-Based Targets for Establishing, New Woodlands can Limit or Underplayntheir Climate Change Mitigation Benefits", Institute of Biological and Environmental Science, 2020, http://doi.org/10.1016/j.landusepol.2020.104690, pp 1-13.

[8] B S Olek, "Experimental Insights into Consolidation rates during one-dimensional loading with Special Reference to Excess Pore Water Pressure", Acta Geotechnica, 2020, https://doi.org/10.1007/s11440-020-01042-3, pp 1-21.

[9] Kolay P K, Sii H Y and Taib S N L, "Compressibility Characteristics of Tropical Peat Using Rowe Cell Consolidation", World Journal of Engineering Volume 9 No. 4, 2012, ISSN: 1708-5284, pp 1-10.

[10] R K Rowe and M A Dist, "Protecting the Environment with Geosynthetics 53rd Karl Terzaghi Lecture", ASCE Journal Geotech, 146(9): 04020081, 2020, pp 1-30. 